\title{
Bicaudal $C$ is required for the function of the follicular epithelium during oogenesis in Rhodnius prolixus
}

\author{
Agustina Pascual $^{1}$ (1) Emiliano S. Vilardo ${ }^{2}$ - Catalina Taibo $^{3}$ - Julia Sabio y García ${ }^{3} \cdot$ Rolando Rivera Pomar $^{1,2}$
}

Received: 21 September 2020 / Accepted: 9 February 2021 / Published online: 11 March 2021

(C) The Author(s), under exclusive licence to Springer-Verlag GmbH Germany, part of Springer Nature 2021

\begin{abstract}
The morphology and physiology of the oogenesis have been well studied in the vector of Chagas disease Rhodnius prolixus. However, the molecular interactions that regulate the process of egg formation, key for the reproductive cycle of the vector, is still largely unknown. In order to understand the molecular and cellular basis of the oogenesis, we examined the function of the gene Bicaudal C (BicC) during oogenesis and early development of $R$. prolixus. We show that $R$. prolixus BicC $(R p-B i c C)$ gene is expressed in the germarium, with cytoplasmic distribution, as well as in the follicular epithelium of the developing oocytes. RNAi silencing of $R p-B i c C$ resulted in sterile females that lay few, small, non-viable eggs. The ovaries are reduced in size and show a disarray of the follicular epithelium. This indicates that $\mathrm{Rp}-\mathrm{BicC}$ has a central role in the regulation of oogenesis. Although the follicular cells are able to form the chorion, the uptake of vitelline by the oocytes is compromised. We show evidence that the polarity of the follicular epithelium and the endocytic pathway, which are crucial for the proper yolk deposition, are affected. This study provides insights into the molecular mechanisms underlying oocyte development and show that $R p-B i c C$ is important for de developmental of the egg and, therefore, a key player in the reproduction of this insect.
\end{abstract}

Keywords Bicaudal C $\cdot$ Vitellogenesis $\cdot$ Follicular cells $\cdot$ Oogenesis $\cdot$ Embryonic development

\section{Introduction}

Rhodnius prolixus is a hematophagous insect and, like other triatomines, is the vector of Trypanosoma cruzi, the causative agent of Chagas disease (Coura and Borges-Pereira 2012; Chagas 1909). In addition to the sanitary relevance, $R$. prolixus has been a classical model of physiology since the pioneer studies of Sir Vincent Wigglesworth (Wigglesworth 1934, 1939, 1953, 1964) and, to some extent,

Communicated by Siegfried Roth

Agustina Pascual

apascual@comunidad.unnoba.edu.ar

Rolando Rivera Pomar

rrivera@unnoba.edu.ar

1 Centro de Bioinvestigaciones (UNNOBA-CICBA), CITNOBA (UNNOBA-CONICET), 2700, Pergamino, Buenos Aires, Argentina

2 Centro Regional de Estudios Genómicos (Facultad de Ciencias Exactas, CREG-UNLP), 1900, La Plata, Buenos Aires, Argentina

3 Laboratorio de Microscopia Integral (LIM), (CICVyA, INTA), 1686, Hurlingham, Buenos Aires, Argentina an emerging model for developmental biology (Berni et al. 2014; Lavore et al. 2014; Lavore et al. 2012). The genome of $R$. prolixus has been sequenced (Mesquita et al. 2015), several tissue-specific transcriptomes have been analyzed (Medeiros et al. 2011a; Ribeiro et al. 2014), as well as developmental studies of ovaries and embryos (Brito et al. 2018; Lavore et al. 2015) providing a solid foundation for gene identification. The development of molecular tools such as parental RNA interference (RNAi) (Lavore et al. 2012) set the ground for functional analysis.

Oogenesis is a period of rapid cellular growth and differentiation, implying the differentiation of the oocyte from a niche of stem cells in the germ line, the accumulation of yolk, formation of the chorion, and the establishment of the future embryo axes. These events are entangled in a regulated manner by means of the communication between the different cell types that compose the ovary, hormonal signaling, and gene expression (Lynch and Roth 2011). Insect ovaries are classified into three distinct types: panoistic, polytrophic, and telotrophic, based on the morphology of germ cells in the mature ovary (Bonhag 1958; Davey 1965; de Cuevas 2005; Snodgrass 1935; Urbani 1970). The morphology and architecture of the ovaries have been studied in a variety of insects 
(Büning 1994; de Cuevas 2005; Fortes et al. 2011; Huebner and Anderson 1972a, 1972b, 1972c; Huebner and Injeyan 1981; Lutz and Huebner 1980), but a detailed understanding of the regulatory gene network have only been determined in Drosophila melanogaster (Driever and Nusslein-Volhard 1988a, 1988b; Nusslein-Volhard and Roth 1989; Roth and Schupbach 1994; Schupbach and Roth 1994; Schupbach and Wieschaus 1986).

The adult females of $R$. prolixus have two telotrophic type ovaries, each one made up of seven ovarioles (Huebner 1981a). Each ovariole is composed with nurse cells confined in a distal chamber referred to as the trophic chamber or tropharium, separated from the vitellarium, in which oocytes go through the different stages of oogenesis, previtellogenesis, vitellogenesis, and choriogenesis, accompanied by the follicular epithelium (Huebner 1981b; Huebner and Anderson 1972b). Oogenesis is triggered by feeding (Buxton 1930). The trophic chamber produces maternal RNAs and nutrients, which are transported to the developing oocyte through tubular bridges - the trophic cords, in a directional transport mediated by a network of microtubules (Harrison and Huebner 1997; Valdimarsson and Huebner 1989). The accompanying follicle cells shows dramatic morphological and physiological changes during the different stages of oogenesis, but they always keep an organized pattern (Huebner and Anderson 1972b). Together with the fat body, the follicular cells are responsible for the synthesis of vitellogenin $(\mathrm{Vg})$, precursor of vitellin ( $\mathrm{Vn}$ ), the main component of egg yolk (Melo et al. 2000; Oliveira et al. 1986; Raikhel 2005; Raikhel and Dhadialla 1992). Later on, follicle cells produce the outermost layer of the egg, the chorion, which protects egg from dehydration and regulates oxygen intake and fertilization (Beament 1946). Despite the extensive morphological and biochemical studies (Atella et al. 2005; Harrison and Huebner 1997; Huebner and Anderson 1972a, 1972b, 1972c; Lutz and Huebner 1981; Oliveira et al. 1986). Fundamental evidence on the physiological network based on the transcriptome analysis of fat body and ovary has just emerged in $R$. prolixus through the pioneer work of Leyria et al. (2020). However, the regulatory gene networks required for proper egg formation and patterning remains to be studied.

Many orthologues of the genes involved in D. melanogaster oogenesis have been identified in $R$. prolixus (Medeiros et al. 2011a; Mesquita et al. 2015; Pascual 2019), one of this was Bicaudal $C$ (BicC). BicC was originally identified in a D. melanogaster maternal mutagenesis screen (Mohler and Wieschaus 1986; Nusslein-Volhard 1977; Schupbach and Wieschaus 1991). Females heterozygous for BicC mutations produce embryos of several different phenotypic classes, including bicaudal embryos that consist only of a mirror-image duplication of 2-4 posterior segments. Homozygous $\mathrm{BicC}$ females are sterile because the centripetal follicle cells fail to migrate over the anterior surface of the oocyte at stage 10 during D. melanogaster oogenesis (Mahone et al. 1995; Nusslein-Volhard 1977; Schupbach and Wieschaus 1991). BicC encodes a protein with hnRNP K homology $(\mathrm{KH})$ and sterile alpha motif (SAM) domains (Mahone et al. 1995), both RNA-binding motifs (Aviv et al. 2006; Chmiel et al. 2006; Johnson and Donaldson 2006) that interact with other proteins related to RNA metabolism and targets mRNAs to form regulatory ribonucleoprotein complexes (Chicoine et al. 2007). Also, it has been reported to be involved in the function of Malpighian tubules in the adults (Gamberi et al. 2017).

Here, we report the function of Bicaudal C (Rp-BicC) during oogenesis of $R$. prolixus. We identified the expression of $B i c C$ gene and carried out parental RNAi experiments. Our results show that $R p-B i c C$ is required for the proper follicular epithelium function, affecting yolk uptake and chorion patterning.

\section{Materials and methods}

\section{Insect husbandry}

A colony of Rhodnius prolixus was maintained in our insectarium of the Centro de Bioinvestigaciones (CeBio) in plastic jars containing strips of paper at $28{ }^{\circ} \mathrm{C}$ and $80 \%$ relative humidity in controlled environment incubators with a 12 $\mathrm{h}$ light/dark cycle. In this condition, embryogenesis takes $14 \pm$ 1 days. Insects were regularly fed on chicken, ad libitum, which were housed, cared, fed, and handled in accordance with resolution 1047/2005 (National Council of Scientific and Technical Research, CONICET) regarding the national reference ethical framework for biomedical research with laboratory, farm, and nature collected animals, which is in accordance with the international standard procedures of the Office for Laboratory Animal Welfare, Department of Health and Human Services, NIH, and the recommendations established by the 2010/63/EU Directive of the European Parliament, related to the protection of animals used for scientific purposes. Biosecurity rules fulfill CONICET resolution 1619/2008, which is in accordance with the WHO Biosecurity Handbook (ISBN 924354 6503).

\section{Identification of the BicC transcript and CDNA synthesis}

The transcript was identified by local BLASTX search (Altschul et al. 1990) using the D. melanogaster orthologue gene as query on transcriptomes from ovary and different early embryonic stages, assembled using the annotated genome of $R$. prolixus as reference (VectorBase, RproC3 version; Pascual and Rivera Pomar unpublished data). The predicted sequence was aligned with orthologues from other species with ClustalW (Larkin et al. 2007). Phylogenetic tree was 
inferred with the software BEAST v1.10.4 (Drummond and Rambaut 2007) in the CIPRES Science Gateway (Miller et al. 2010). The result was visualized with iTol online tool (Letunic and Bork 2016).

$R$. prolixus embryos at different pre-gastrulation developmental times were collected and used for RNA extractions, performed with TRIzol (Invitrogen) according to the manufacturer's instructions. cDNA was synthesized using SuperScript ${ }^{\mathrm{TM}}$ VILO ${ }^{\mathrm{TM}}$ MasterMix kit (Invitrogen) and used as template for PCR. Specific primers for $R p-B i c C$ were designed (Rozen and Skaletsky 2000; Stothard 2000) to amplify two different regions within the KH domain $R p-B i c C^{l}(237$ bp): sense-1 5'-CAAGGCACGTCAACAGCTAA-3', antisense-1 $5^{\prime}$-GGATCGTTAGGAGCGATCAA-3'; and $R p$ Bic $^{2}$ (291 bp): sense-2 5'-CGACTCAAACTTGG TGCAAA-3', antisense-2 5'-AACTTCGCCAGCGA TAGAAA- $3^{\prime}$. The reaction conditions were $5 \mathrm{~min}$ at $94{ }^{\circ} \mathrm{C}$, followed by 35 cycles of $30 \mathrm{~s}$ at $94{ }^{\circ} \mathrm{C}, 30 \mathrm{~s}$ at $60{ }^{\circ} \mathrm{C}$ and $35 \mathrm{~s}$ at $72{ }^{\circ} \mathrm{C}$, and a final extension of $5 \mathrm{~min}$ at $72{ }^{\circ} \mathrm{C}$. Amplicons were separated in $1 \%$ agarose gels, and sequenced to confirm identity (Macrogen Inc.). In addition, the same primers were designed containing T7 promoter sequence (CGACTCAC TATAGGG) at the 5'end for use for in vitro transcription of dsRNA or antisense RNA probes.

Fat body and ovaries were dissected, in phosphate-buffered saline (PBS $1 \times$ ), from adult females in which oogenesis was induced ( $144 \mathrm{~h}$ post-feeding). Each tissue sample was grouped in pools of three organs, placed in TRIzol reagent, and kept frozen until use. cDNA synthesis and PCR amplification was performed in the same conditions mentioned previously.

\section{Real-time quantitative PCR}

Adult mated insects ( 6 days after feeding) were used to collect eggs at different developmental times - unfertilized, 0, 12, 24, and $48 \mathrm{~h}$ post-egg laying (hPL), and ovaries in vitellogenic stage, were immediately frozen and stored in liquid nitrogen until use. For each sample, 75 embryos in each stage and 10 vitellogenic ovaries were used to extract RNA for qRT-PCR.

Total RNA was isolated using TRIzol reagent (Invitrogen) and treated with DNAse (QIAGEN). cDNA was synthesized using SuperScript ${ }^{\mathrm{TM}}$ VILO $^{\mathrm{TM}}$ MasterMix kit (Invitrogen) following the manufacturer's instructions. qRT-PCR was performed on three independent biological replicates, in triplicate (3 wells/cDNA sample), in a $10 \mu$ final volume. Gene expression levels were quantified using SsoAdvanced Universal SYBR Green Supermix (Bio-Rad) in an Applied Biosystems 7.500 Real-Time PCR System (Thermo Fisher, Scientific). The amplification protocol was as follows: $95^{\circ} \mathrm{C}$ for $10 \mathrm{~min}$ followed by 35 cycles $\left(95{ }^{\circ} \mathrm{C} 15 \mathrm{~s} / 55^{\circ} \mathrm{C} 30 \mathrm{~s} / 72{ }^{\circ} \mathrm{C} 45 \mathrm{~s}\right)$. A control without a template was included in all experiments. $\alpha$ Tubulin were used as reference gene $(R p-\alpha T u b(220 \mathrm{bp})$ sense: 5'-CAAATAATTACGCCCGAGGA-3' and antisense:
5'-TTGAGGAGCTGGGTAAATGG-3'). All primer pairs used for qRT-PCRs were tested for dimerization, efficiency, and amplification of a single product. The $\mathrm{Ct}$ value was averaged for the technical triplicate experiments and subtracted from the average $\mathrm{Ct}$ of the reference gene, to yield the expression difference $(\mathrm{dCt})$ for each biological replicate. The results were analyzed according to (Ginzburg et al. 2017). To test whether the expression of $R p-B i c C$ was significantly different between the different stages, one-way ANOVA was carried out followed by post hoc test using the GraphPad Prism v6.0 software (GraphPad Software, CA, USA, www.graphpad. com).

\section{Ovary and embryo manipulation}

Control and silenced adult females were fed to induce oogenesis, and 5 days later, the ovaries were dissected in PBS $1 \times$. Ovaries were fixed in different ways depending on the subsequent analysis. For confocal microscopy, the fixation was performed on ice in $4 \%$ paraformaldehyde (PFA) in PBT (PBS $1 \times+0.1 \%$ Tween-20) for $30 \mathrm{~min}$, then washed three times in PBT and stored at $4{ }^{\circ} \mathrm{C}$ until staining the nuclei with Hoechst (Sigma-Aldrich, USA, $1 \mu \mathrm{g} / \mathrm{ml}$ ). Images were acquired with the Zeiss LSM 800 confocal microscope. For light microscopy, ovaries were fixed in formaldehyde $4 \%$, washed with Millonig's buffer, dehydrated in graded series of ethanol $(70 \%, 96 \%, 100 \%)$ and xylene $(100 \%)$ and embedded in paraffin (Wanderley-Teixeira et al. 2006). Five-micrometer-thick sections were cut in a rotary microtome (Leica) and stained using standard hematoxylin-eosin procedure, mounted and photographed using an A1 ZEISS microscope. For transmission electron microscopy (TEM), the protocol was modified from Huebner and Anderson (1970). Ovaries were fixed in glutaraldehyde $2.5 \%$ and post-fixed in $1 \%$ osmium tetroxide in Millonig's buffer at $\mathrm{pH}$ 7.4. This was followed by dehydration in a graded series of ethanol $(25 \%, 30 \%, 50 \%, 80 \%, 90 \%)$ and acetone (100\%), after which the ovaries were infiltrated and embedded in epoxy resin (Durcupan ACM, Fluka AG, Switzerland). Ultrathin sections $(\sim 60 \mathrm{~nm})$ were cut with a diamond knife, stained with aqueous uranyl acetate and Reynold's lead citrate (Reynolds 1963), and examined at $80 \mathrm{kV}$ in a MET JEOL 1200 EXII transmission electron microscope.

For the analysis of lipids and membranes distribution, lipophilic styryl dye FM 4-64FX (Thermo Fisher Scientific) was injected in the body cavity of females in a 1:500 dilution (3 $\mu \mathrm{g} / \mu \mathrm{l})$ in PBS $1 \times$ and let to diffuse for $20 \mathrm{~min}$. FM 4-64FX targets plasma membrane and marks exo/endocytosis hot spots in the cells (Smith and Betz 1996). For the dextran oocyte uptake analysis, $2 \mu$ of Texas Red-conjugated dextran (10,000 MW; Molecular probes, Thermo Fisher Scientific) was injected between abdominal tergites in the hemocoel of females 4 days after blood meal and incubated $24 \mathrm{~h}$. After the 
corresponding time, ovaries were dissected and fixed as described above for confocal microscopy and images were acquired in a Zeiss LSM 800 confocal microscope.

Eggs collected from individual females were used for scanning electron microscopy (SEM), fixed in glutaraldehyde $2.5 \%$, washed with Millonig's buffer, dehydrated in a graded series of ethanol $(70 \%, 96 \%, 100 \%)$, mounted with doublesided adhesive carbon tape on metallic stubs, metallized with gold and observed under a SEM Quanta 250 (FEI) operated at $20 \mathrm{kV}$ (Sorrivas de Lozano et al. 2014).

\section{Fluorescent immunohistochemistry}

Ovaries were fixed for confocal microscopy, then washed in PBS (0.1\% Triton X-100 in PBS), blocked with 5\% normal goat serum for $2 \mathrm{~h}$, and incubated overnight at $4{ }^{\circ} \mathrm{C}$ with $1: 200$ dilution of rabbit polyclonal anti-vitellin antibody, which reacted with $\mathrm{Vg} / \mathrm{Vn}$ (Aguirre et al. 2008; Blariza et al. 2016). After extensive washing, the ovaries were incubated for $2 \mathrm{~h}$ at room temperature with secondary Alexa 568conjugated anti-rabbit IgG (1:500 in PBS; Invitrogen, Life Technologies), washed and counterstained with Hoechst (Sigma-Aldrich, USA, $1 \mu \mathrm{g} / \mathrm{ml}$ ) before image acquisition in a ZEISS LSM 800 confocal microscope.

\section{RNA in situ hybridization}

Digoxigenin-labeled antisense $R p-B i c C$ RNA probes were synthesized using the RNA-Dig Labeling kit (SP6/T7) (Roche). In situ hybridization was carried out in $4 \%$ PFA fixed ovaries stored in PBT at $4{ }^{\circ} \mathrm{C}$. The ovaries were post-fixed in $\mathrm{PBT}+$ fixative solution $\left(10 \%\right.$ PFA in PBS + EGTA- $\mathrm{Na}_{2}$ ) for $20 \mathrm{~min}$ on a rocking platform at room temperature. The ovaries were washed three times with PBT and digested with proteinase $\mathrm{K}(10 \mathrm{mg} / \mathrm{ml})$ for $15 \mathrm{~min}$ and post-fixed as before, following three PBT washes. A pre-hybridization step was performed for $2 \mathrm{~h}$ at $60{ }^{\circ} \mathrm{C}$ in Hybe $(50 \%$ formamide, $5 \mathrm{x}$ SSC, $0.2 \mathrm{mg} / \mathrm{ml}$ Sonicated salmon testes DNA, $0.1 \mathrm{mg} / \mathrm{ml}$ tRNA, $0.05 \mathrm{mg} / \mathrm{ml}$ heparin, $0.1 \%$ Tween-20) before the addition of the probe and further incubated overnight at $60{ }^{\circ} \mathrm{C}$. The ovaries were rinsed three times with Hybe-B (50\% formamide, $5 \times$ SSC, $0.1 \%$ Tween- 20 ) and then washed in Hybe-C (50\% formamide, $2 \times \mathrm{SSC}, 0.1 \%$ Tween-20) during $2 \mathrm{~h}$ at 60 ${ }^{\circ} \mathrm{C}$, and further washed three times with PBT. The hybridized samples were blocked with antibody-hybridization solution ( $0.2 \%$ Tween- $20,1 \mathrm{mg} / \mathrm{ml}$ bovine serum albumin, $5 \%$ normal goat serum) for $3 \mathrm{~h}$ at room temperature and then incubated overnight with alkaline phosphatase-conjugated anti-DIG Fab fragments (Roche, 1:2000) at $4{ }^{\circ} \mathrm{C}$ on a shaking platform. The antibody was washed away three times with PBT and one time with alkaline staining buffer (100 mM TRIS, $100 \mathrm{mM} \mathrm{NaCl}$, $0.1 \%$ Tween-20). The enzymatic activity revealed with NBT/ $\mathrm{BCIP}$ (Roche). When staining was evident, the ovaries were washed in PBT three times to stop the reaction, dehydrated in a graded series of ethanol, and mounted in glycerol for observation and image acquisition using A1 ZEISS microscope.

\section{Parental RNA interference}

Double-stranded RNA (dsRNA) was produced by simultaneous transcription with T7 RNA polymerase (New England Biolabs) on PCR products containing T7 promoter sequences (CGACTCACTATAGGG) at both ends. Two independent templates, dsRNA ${ }^{B i c C 1}$ and dsRNA ${ }^{B i c C 2}$, were used for independent experiments to evaluate potential off-target effects. dsRNA was quantitated and injected into virgin females, using different concentrations, as described in Lavore et al. (2012). Two days after injection, the females were fed to induce oogenesis and mated with males. After mating, eggs were collected and ovaries fixed as indicated above. A negative control was performed injecting virgin females with dsRNA corresponding to the $\beta$ - lactamase gene $\left(\operatorname{dsRNA}^{\beta-l a c}\right.$ ) of Escherichia coli gene (Lavore et al. 2012).

\section{Results}

\section{The $R p$-BicC transcript is expressed in ovaries and early embryos}

$R p-B i c C$ was identified in transcriptomes derived from ovaries, unfertilized eggs, and early embryos of $R$. prolixus (Pascual and Rivera-Pomar, unpublished data) by sequence similarity search against $D$. melanogaster orthologue. The assembled $R p-B i c C$ transcript from these RNA-seq dataset corresponds to the ab initio annotated transcriptional units RPRC0001612 and RPRC001613 within the supercontig KQ034133, indicating that the two different predictions in Vector Base (https://www.vectorbase.org/) were erroneous, and that they correspond to a single transcriptional unit (Fig. 1a). The transcript (1986 bp) derives from 14 exons and encodes a predicted polypeptide of 662 amino acids. Multiple alignment of $B i c C$ orthologous sequences showed that $R p$ $B i c C$ conserve the typical $\mathrm{KH}$ and SAM domains as other species (Fig. 1b and Supplementary Fig. 1).

Reads from the $R p-B i c C$ transcript were identified in all of the transcriptomes corresponding to the different stages come from ovaries, unfertilized eggs, and early embryos at $0,12,24$, and $48 \mathrm{~h}$ post-egg laying (hPL; Pascual and Rivera-Pomar, unpublished data), indicating that the transcript is maternally contributed, although the zygotic expression cannot be ruled out. The relative expression level of $R p-B i c C$ was assessed by qPCR. $R p-B i c C$ was detected in all of the analyzed stages, showing a higher expression from unfertilized eggs up to $12 h P L$, with a significant decrease in the expression levels after on (Fig. 1c). In situ hybridization validated the 
a

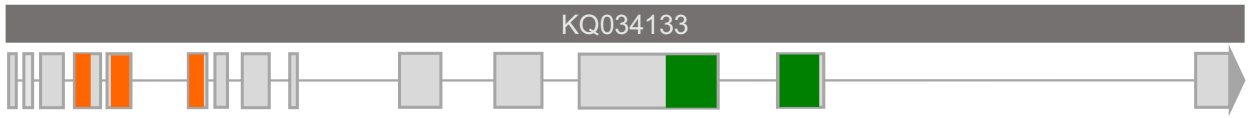

b
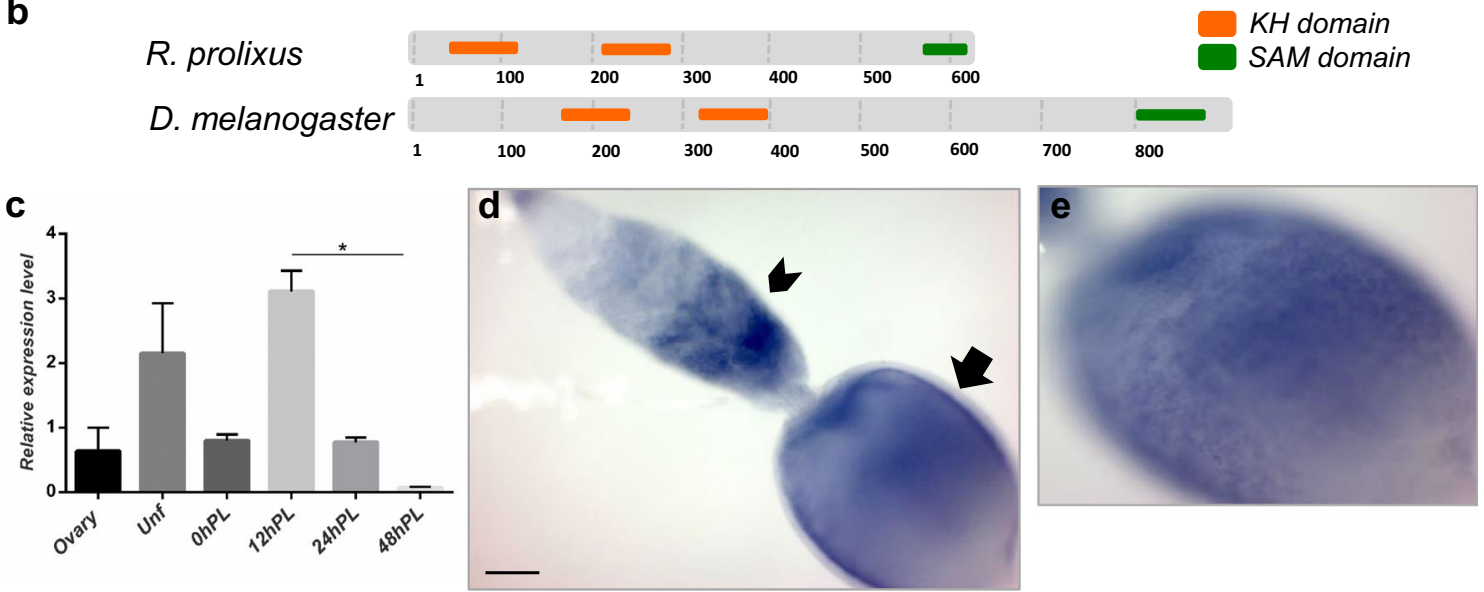

Fig. 1 Structure and expression of $R$. prolixus Bicaudal $C$ (Rp-BicC). a Scheme of the gene structure. Solid gray bar represents the supercontig that contains the $R p-B i c C$ transcriptional unit. The light gray boxes represent exons. b Diagram of the predicted conserved functional domains of Bicaudal $C$ in $R$. prolixus and D. melanogaster domains. c Real-time quantitative PCR of $R p-B i c C$ expression. Results are expressed as mean \pm SEM of 3 independent experiments. The $Y$-axis represents

expression of $R p$-BicC transcript in the ovaries, showing cytoplasmic distribution in both, the germarium (Fig. 1d, arrowhead) and the follicular epithelium of previtellogenic and vitellogenic oocytes (Fig. 1d, e).

\section{$R p-B i c C$ is required for proper egg formation}

To determine the role of $R p-B i c C$, we injected non-fed virgin females $(n=17)$ with different concentrations (ranging from 0.7 to $2.5 \mu \mathrm{g} / \mathrm{female}$ ) of two independent dsRNA corresponding to different regions of the transcript (dsRNA ${ }^{B i c C l}, 237 \mathrm{bp}$ and dsRNA ${ }^{B i c C 2}, 291 \mathrm{bp}$ ). As control, we used dsRNA corresponding to the $\beta$-lactamase gene of $E$. coli $\left(\mathrm{dsRNA}^{\beta-l a c}\right)$. After feeding and mating, dsRNA ${ }^{R p-B i c C 1}$, dsRNA ${ }^{B i c C 2}$, and dsRNA $^{\beta-l a c}$ injected females were evaluated for egg deposition and morphology, ovary phenotype, and embryo lethality. The number of eggs laid by the interfered females is significantly less than the control (Mann-Whitney statistical test for $\operatorname{dsRNA}^{R p-B i c C 1} P<0.01$; dsRNA $\left.{ }^{B i c C 2} P<0.05\right)$ indicating that $R p$-BicC is required for fertility (Table 1). To determine lethality, the eggs were incubated to develop for the expected time of embryogenesis to finish (> 14 days). None of the eggs from interfered females resulted in hatchlings, indicating that the embryogenesis was affected. The dissection of the eggs did not show any distinguishable embryonic structure, suggesting that $\mathrm{BicC}$ might act at very early stages of development. The eggs laid by the silenced females, as opposed to the control ones, were smaller, with irregular shape, and showed expression relative to the reference gene. Ovary samples were collected in a vitellogenic state ( $144 \mathrm{~h}$ post-feeding). $* P$ value $<0.1$. e Detection of $R p-B i c C$ transcript in the ovarioles by in situ hybridization. The arrowhead indicates the expression in distal part of the tropharium; the arrow indicates the expression in the vitellogenic oocyte. Scale bar: $100 \mu \mathrm{m} . \mathbf{f}$ Different focal plane of the vitellogenic oocyte showed in e. Note the expression of $R p-B i c C$ in the follicular cells

white coloration instead the characteristic pink (Fig. 2a), indicating the absence or significant reduction of the Rhodnius heme-binding protein (RHBP, an important component of the yolk). The $R p-B i c C$ interfered eggs showed an irregular surface. To determine if there is a structural alteration in the chorion morphology we performed scanning electron microscopy. Compared to the regular hexagonal pattern of the chorion observed in the control (Fig. 2b), the eggs derived from the silenced females showed defects in the chorion structure, showing an irregular pattern, prominences, and a shrunken surface (Fig. 2c). The operculum is deformed, although it has a similar size as the control ones. This results indicates that the chorion and chorionic structures are formed, but the patterning is dramatically affected.

\section{$R p$-BicC is required for the development of follicular epithelium during oogenesis}

To further investigate the effect of $R p-B i c C$, we studied the morphology of the ovary. The ovaries of the $R p-B i c C$ silenced females have the same number of ovarioles as the control, but they are reduced in size (Fig. 3a-f). We analyzed the morphology under DIC optics (Fig. 3b, e) and by staining the nuclei to determine cell distribution (Fig. 3c, f). Compared to the control (Fig. 3b), the follicular epithelium of the $R p-B i c C$ silenced females was folded and wrinkled (Fig. 3c) and both, previtellogenic and vitellogenic oocytes were smaller (Fig. $3 \mathrm{~b}, \mathrm{c})$. The ovaries of $R p-B i c C$ silenced females did not 
Table 1 Summary of parental RNAi experiment. The statistical significance of the data was calculated using Mann-Whitney test. A $p$ value $<0.05$ was considered statistically significant. $* p<0.05 ; * * p<0.01$ with respect to control group (dsRNA ${ }^{\text {Blac }}$ )

\begin{tabular}{|c|c|c|c|c|c|c|}
\hline & ${ }_{\text {ds }}$ RNA dosage & $\begin{array}{l}\text { Number of } \\
\text { injected females }\end{array}$ & Ovipositions & Ovary phenotype & Egg phenotype & Embryo lethality \\
\hline \multirow[t]{3}{*}{${ }_{\mathrm{ds}} \mathrm{RNA}^{B i c C l}{ }_{*}$} & $0.77 \mu \mathrm{g}$ & 2 & 16 & $2 / 2(100 \%)$ & $16 / 16(100 \%)$ & $16 / 16(100 \%)$ \\
\hline & $1.2 \mu \mathrm{g}$ & 1 & 6 & $1 / 1(100 \%)$ & $6 / 6(100 \%)$ & $6 / 6(100 \%)$ \\
\hline & $2 \mu \mathrm{g}$ & 2 & 37 & $2 / 2(100 \%)$ & $37 / 37(100 \%)$ & $37 / 37(100 \%)$ \\
\hline \multirow[t]{4}{*}{${ }_{\mathrm{ds}} \mathrm{RNA}^{B i c C 2}{ }_{* *}$} & $0.8 \mu \mathrm{g}$ & 4 & 5 & $4 / 4(100 \%)$ & $5 / 5(100 \%)$ & $5 / 5(100 \%)$ \\
\hline & $1.5 \mu \mathrm{g}$ & 3 & 50 & $3 / 3(100 \%)$ & $50 / 50(100 \%)$ & $50 / 50(100 \%)$ \\
\hline & $2 \mu \mathrm{g}$ & 4 & 67 & $4 / 4(100 \%)$ & $67 / 67(100 \%)$ & $67 / 67(100 \%)$ \\
\hline & $2.5 \mu \mathrm{g}$ & 1 & 24 & $1 / 1(100 \%)$ & $24 / 24(100 \%)$ & $24 / 24(100 \%)$ \\
\hline \multirow[t]{2}{*}{${ }_{\mathrm{ds}} \mathrm{RNA}^{\text {Blac }}$} & $1 \mu \mathrm{g}$ & 2 & 72 & $0 / 2(0 \%)$ & $0 / 72(0 \%)$ & $5 / 72(6.94 \%)$ \\
\hline & $2 \mu \mathrm{g}$ & 2 & 148 & $0 / 2(0 \%)$ & $0 / 148(0 \%)$ & $3 / 148(2.02 \%)$ \\
\hline
\end{tabular}

evidence to show significant morphological differences in the germarium, but displayed the absence of the large nucleoli characteristic of the trophic chamber. From previtellogenic stages on, we observed that the regular organization of the follicular cells is lost (Fig. 3e, f). Thin sections of the ovary stained with hematoxylin/eosin showed that, as compared to the control ones (Fig. 3d), silenced females displayed oocytes with irregular yolk distribution, accompanied by diminished number of yolk granules and presence of empty spaces in the cytoplasm. The follicular cells appear detached one from each other and the irregular columnar epithelium showed increased intercellular space (Fig. 3h). Transmission electron microscopy analysis indicates that, compared to the control (Fig. 3i), follicular cells of the $R p-B i c C$ silenced females lack their contact with the basal membrane and tunica propria, reduction of the contacts that keep them together in a regular manner, and show vesiculated cytoplasm and less dense nucleoli (Fig. 3j). This results agrees with the observed phenotype of the chorion and indicate that the follicular cells are able to form the chorion, despite the disarray of the cells.

\section{$R p$-BicC affects the vesicle trafficking and polarity of follicle cells}

In order to address the functional characterization of the morphological changes observed in the follicular epithelium, we analyzed if the transport of molecules, from the hemolymph to the oocyte was affected. We first analyzed if the yolk uptake by the oocyte was affected; for this, we used an antibody to localize the presence of vitellin/vitellogenin in the developing oocytes. In control females, we observed that vitellogenic oocytes accumulates vitellogenin within the cytoplasm of follicle cells (Fig. 4a-c). The ovaries of silenced females, compared to the control, showed a dramatic decrease of the antivitellogenin signal (Fig. 4d-f). A closer look showed that vitellogenin was concentrated in granules in the apical region of the follicle cells of the control females (Fig. 4g), while in the silenced females, we observed a dramatic decrease in the number of granules and intensity of fluorescent signal, although we cannot rule out a dispersed localization of the signal (Fig. 4h). However, to rule out an extra ovarian effect of $R p-B i c C$ in the uptake of vitellogenin, we evaluated if the expression of $\mathrm{Rp}-\mathrm{BicC}$ in ovaries and fat body, where circulating vitellogenin is synthesized, of the silenced females. Only the ovaries showed a reduced expression of $R p-B i c C$ (Supplementary Fig. 2). This suggests a link between $R p$ $\mathrm{BiCC}$ and the amount of vitellogenin in the follicular cells. We could hypothesize that the disordered follicular epithelium affects the vitellogenin diffusion through the extracellular space (patency) to the oocyte surface. To evaluate whether the uptake of macromolecules is affected, we injected fluorescent dextran (MW $10 \mathrm{kDa}$ ) in the abdominal cavity of both, control and silenced females, and analyzed the differences in the uptake of the fluorescent dextran into the oocyte. In control females, the vitellogenic oocytes accumulate fluorescent dextran (Fig. 5a; the general morphology of the ovariole is shown by Hoechst staining in Fig. 5b), while the vitellogenic oocytes of the $R p-B i c C$ silenced females shows a dramatic reduction of fluorescent dextran intake (Fig. 5c; morphology in Fig. 5d). Taken together, these results support the notion that the transport of macromolecules requires an organized follicular epithelium, for which $R p$-BicC seems to have a key role.

To study if the disordered epithelium has affected the polarity of the follicular cells, we used a lipophilic styryl dye to mark cell membrane and nascent endosomes that spread into the cytoplasm. In the ovaries of control females, we observed fluorescent signal in the apical and basal poles of the follicle cells. This fluorescent signal indicates bona fide regions of endo and exocytosis (Fig. 6a-c). In the ovaries of $R p-B i c C$ silenced females, the fluorescent dye could only be detected in the follicular membrane in the apical pole (Fig. $6 \mathrm{~d}-\mathrm{j}$ ). This 

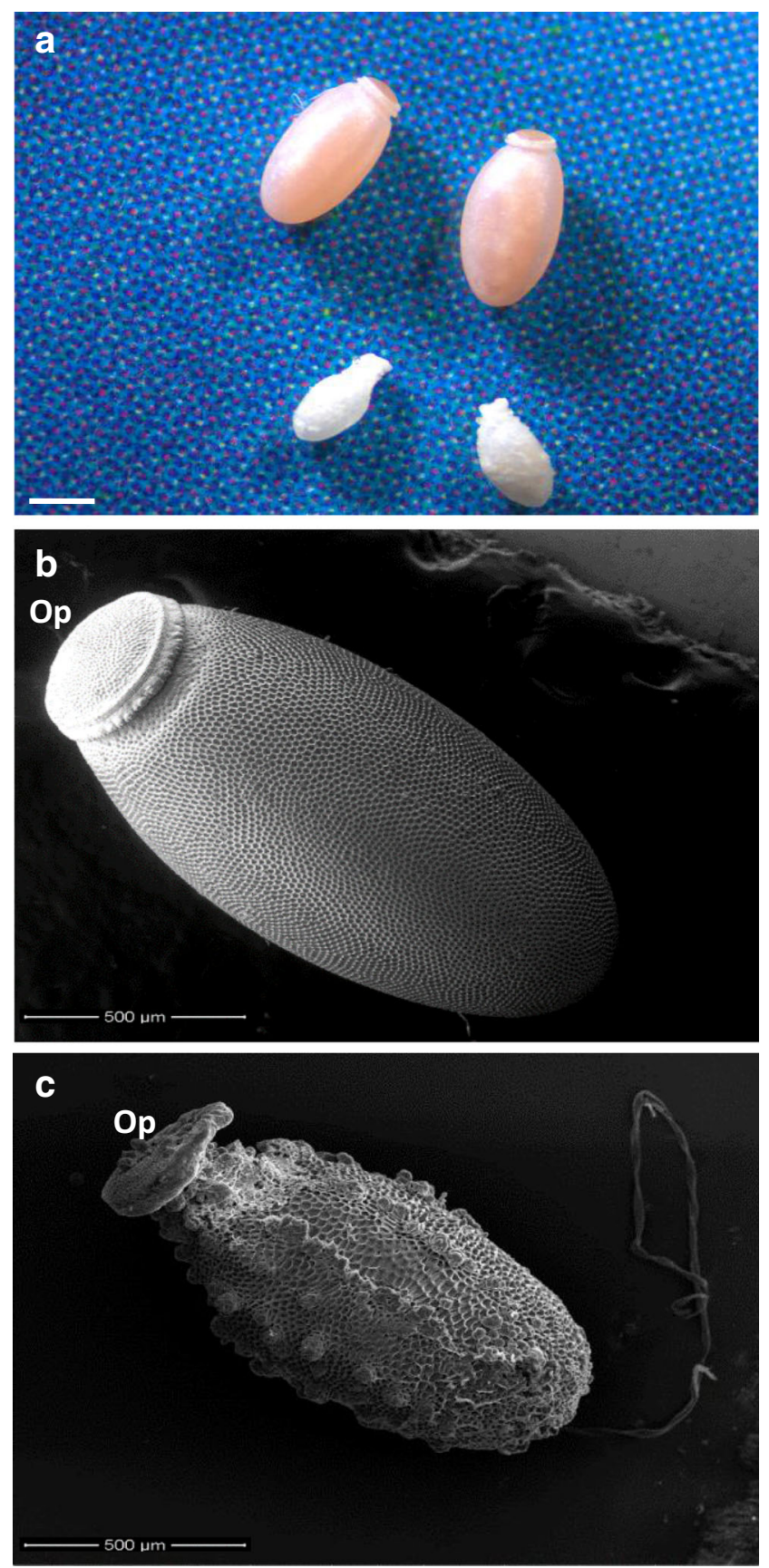

Fig. 2 Silencing of $R p-B i c C$ results in defective chorion formation. a Eggs from control (upper row) and silenced (lower row) females observed with a dissecting microscope. Note the smaller size and the lack of the characteristic pigmentation of the eggs from silenced females. b Scanning electron microscopy image of a control egg. c Scanning electron microscopy image of an egg from interfered female. Scale bar: $500 \mu \mathrm{m}$. Op, operculum, it corresponds to the anterior pole of the egg

suggests that the polarity of the follicular epithelium might be compromised, and therefore, it might affect the communication of the follicle cells with the developing oocyte. Furthermore, the absence of signal in the oocyte membrane agrees with the diminished accumulation of yolk as we showed in the ovaries of $R p-B i c C$ silenced females. Therefore, we conclude that if the endo/exocytic pathway is affected the transport of vitellogenin to the oocyte might be impaired.

\section{Discussion}

$R$. prolixus has been a model system for many essential issues in biology, but the understanding of the molecular mechanisms had to wait until the sequencing of the genome (Mesquita et al. 2015). The oogenesis of $R$. prolixus is one of the best studied among insects, from the morphological work of Huebner (Huebner 1981a; Huebner and Anderson 1972a, 1972b, 1972c; Lutz and Huebner 1980, 1981) to the biochemistry studies of Masuda (Bouts et al. 2007; Braz et al. 2001; Coelho et al. 1997; Costa-Filho et al. 2001; Gondim et al. 1987; Machado et al. 1996; Machado et al. 1998). Studies on the cellular biology of the oogenesis have recently emerged (Pereira et al. 2020; Vieira et al. 2018); however, we still lack genetic information to understand the molecular basis of egg formation and patterning in $R$. prolixus. A transcriptome analysis of the different phases of oogenesis has been reported (Brito et al. 2018) where $R p-B i c C$ was not assigned although one annotated gene was identified (RPRC001612). In this respect, this report on $R p-B i c C$ is the first contribution on a maternal gene required for oogenesis and to provide a bona fide mechanism for egg development and patterning of the chorion not affecting the polarity of the egg. In D. melanogaster, BicC is a maternal gene affecting embryonic anterior-posterior polarity, with a wide range of defects in segmentation (Mohler and Wieschaus 1986; Nusslein-Volhard 1977). We could not identify any embryonic structures in the eggs derived from $\mathrm{Rp}$-BicC silenced females, as we have observed also for other maternal genes (Pagola, Pascual, and Rivera Pomar, unpublished data). This indicates that the role for $\mathrm{Rp}$-BicC in embryogenesis has to be prior to germ band formation and deserves a detailed study in the future.

Cell-to-cell interactions are crucial for the development of oogenesis. It affects both yolk deposition and the signaling from the follicle cells to the oocyte and the later embryogenesis. Based on the expression of $\mathrm{Rp}-\mathrm{BicC}$ in follicle cells and the distribution of vitellogenin and membrane markers in the silenced females, we support the idea that $R p-B i c C$ affects both the morphology and polarity of the follicular epithelium and, likely, the oocyte-follicle cell interaction. This suggests a conserved role for BicC. Biccl (the mouse homologue of $B i c C$ ) is required for E-cadherin-based cell-cell adhesion, indicating that that lack of Biccl disrupts normal cell-cell junctions, and, in consequence, alter epithelial polarity (Park et al. 2016). Disruption of BicC in D. melanogaster affects the normal migration direction of the anterior follicle cell of the oocytes 

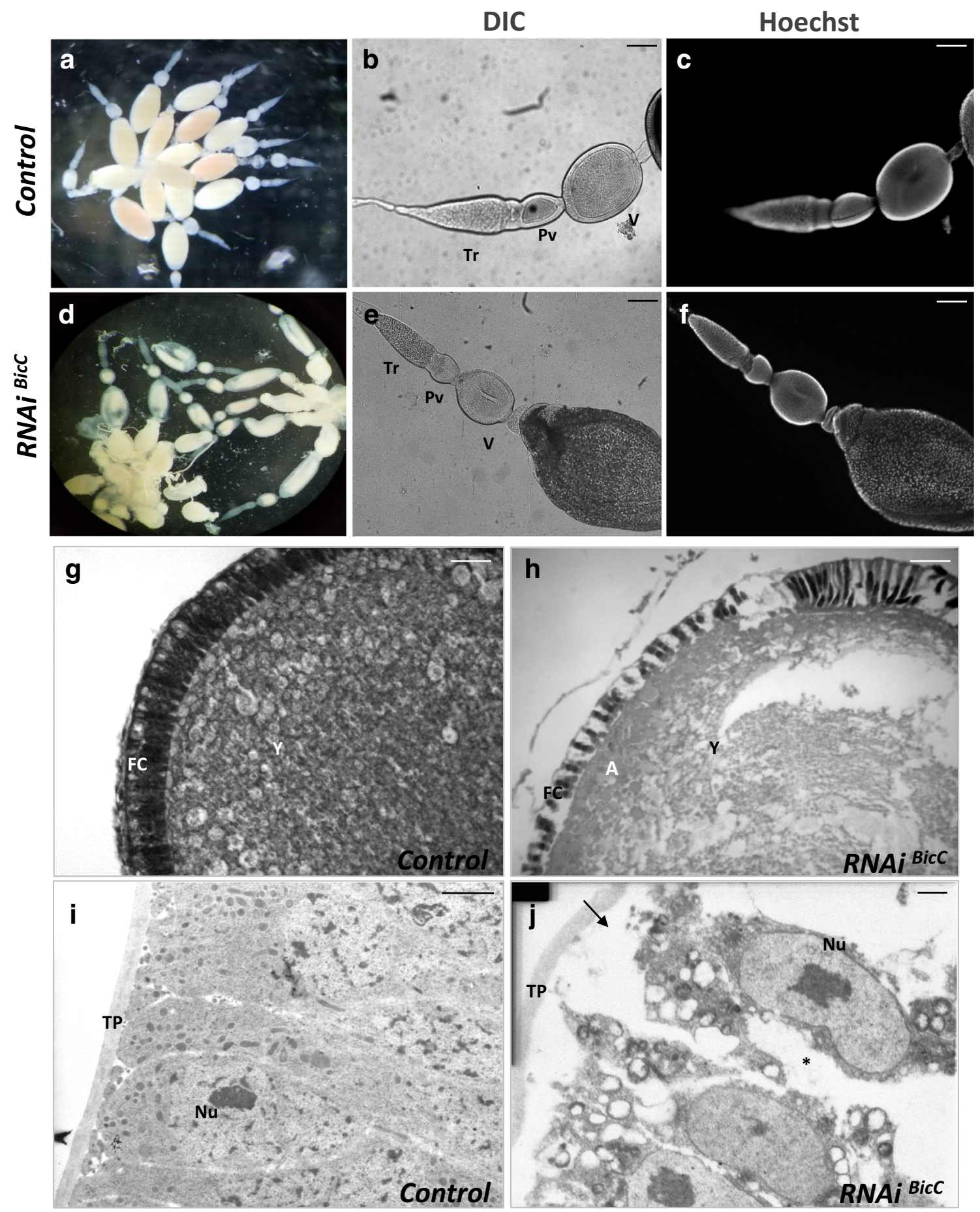

Fig. 3 Silencing of $R p-B i c C$ affects the ovary morphology. a Ovary morphology of a control female under dissecting microscope. b, c Ovariole of a control female showing the tropharium (Tr) and a previtellogenic $(\mathrm{Pv})$ and vitellogenic $(\mathrm{V})$ oocytes by differential interference contrast microscopy (b) and nuclei distribution by Hoechst staining (c); scale bar, $200 \mu \mathrm{m}$. d Ovary morphology of a RNAi ${ }^{B i c C}$ female under dissecting microscope. Note the smaller size of the ovarioles and the lack of pigmentation. e, $\mathbf{f}$ Ovariole of a silenced female showing the tropharium $(\mathrm{Tr})$, a previtellogenic $(\mathrm{Pv})$, and vitellogenic $(\mathrm{V})$ oocytes by differential interference contrast microscopy (e) and nuclei distribution by Hoechst staining (f); scale bar, $200 \mu \mathrm{m}$. Note that the smaller size of the previtellogenic oocyte and the disarray of nuclear distribution of the follicular cells. g Histological staining (hematoxylin-eosin) of a vitellogenic oocyte from control females; scale bar, $10 \mu \mathrm{m}$. FC, follicular cells. Y, yolk. i Transmission electron microscopy (TEM) of a previtellogenic oocyte from control females; scale bar, $2 \mu \mathrm{m}$. TP, Tunica propria; Nu, nucleolus. h Histological section (hematoxylineosin staining) of a vitellogenic oocyte from interfered females; scale bar, $10 \mu \mathrm{m}$. Note the space between follicular cells and the inhomogeneous distribution of yolk. $\mathbf{j}$ Transmission electron microscopy (TEM) of a previtellogenic oocyte from silenced females; Scale bar, $2 \mu \mathrm{m}$. The asterisk marks the intercellular space Intercellular spaces. The arrow indicates lack of contact between the basal membrane and tunica propria 
Fig. 4 Silencing of $R p-B i c C$ alter vitellin uptake in vitellogenic oocytes. a-c Immunostaining using anti-vitellin antibody to determine distribution of vitellin (visualized in red) in the oocytes of control females $(n=7)$. $\mathbf{d}-\mathbf{f}$ Immunostaining using antivitellin antibody to determine distribution of vitellin (visualized in red) in the oocytes of RNAi ${ }^{\text {BicC }}$ females $(n=6)$. All samples were counterstained with Hoechst (blue). Scale bar, $50 \mu \mathrm{m}$. $\mathbf{g}$ Confocal optical section of antivitellin immunostained follicular cells from control females. $\mathbf{h}$ Confocal optical section of antivitellin immunostained follicular cells from silenced $\left(\mathrm{RNAi}^{\text {BicC }}\right)$ females. Scale bar, $10 \mu \mathrm{m}$
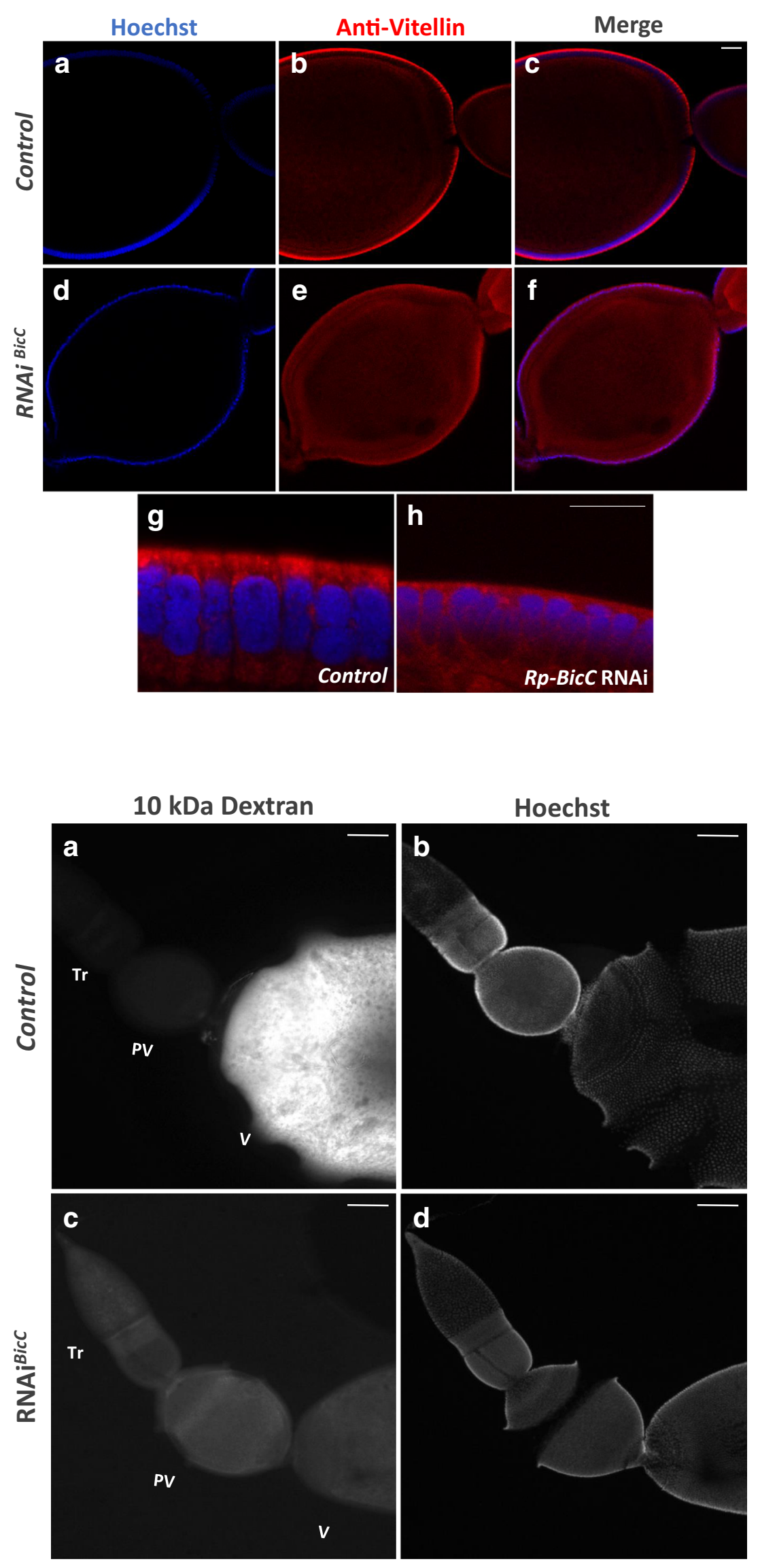

Fig. 5 In vivo dextran uptake in oocytes is prevented in RNAi ${ }^{B i c C}$ females. a Distribution of Texas Red-labeled dextran in vitellogenic oocytes from control females. Tropharium (Tr),

Previtellogenic oocyte $(\mathrm{Pv})$, Vitellogenic oocyte (V). Exposure time, $50 \mathrm{~ms}$. b Counterstaining of control with Hoechst. c Distribution of Texas Red-labeled dextran in vitellogenic oocytes from silenced $\left(\mathrm{RNAi}^{\text {BicC }}\right)$ females.

Exposure time, $100 \mathrm{~ms}$. d Hoechst counterstaining of $\mathbf{c}$. Due to the large size of the ovarioles of $R$. prolixus, some of them might be squashed by the coverslip after mounting resulting in breaking of the follicular epithelia which is not dependent on the interference experiment. Scale bar, $50 \mu \mathrm{m}$ 
Fig. 6 Silencing of $R p-B i c C$ alter lipid distribution in vitellogenic oocytes. a-c Distribution of the FM 4-64FX probe in oocytes after injection of control females $(n=$ 7). $\mathbf{d}-\mathbf{f}$ Distribution of the FM464FX probe in oocytes after injection of silenced $\left(\mathrm{RNAi}^{\text {BicC }}\right)$ females $(n=6)$. Hoechst (a, $\mathbf{d}$, in blue) visualizes DNA; FM 464FX (b, e, in red) stain membranes and endocytic vesicles. Scale bar, $50 \mu \mathrm{m}$
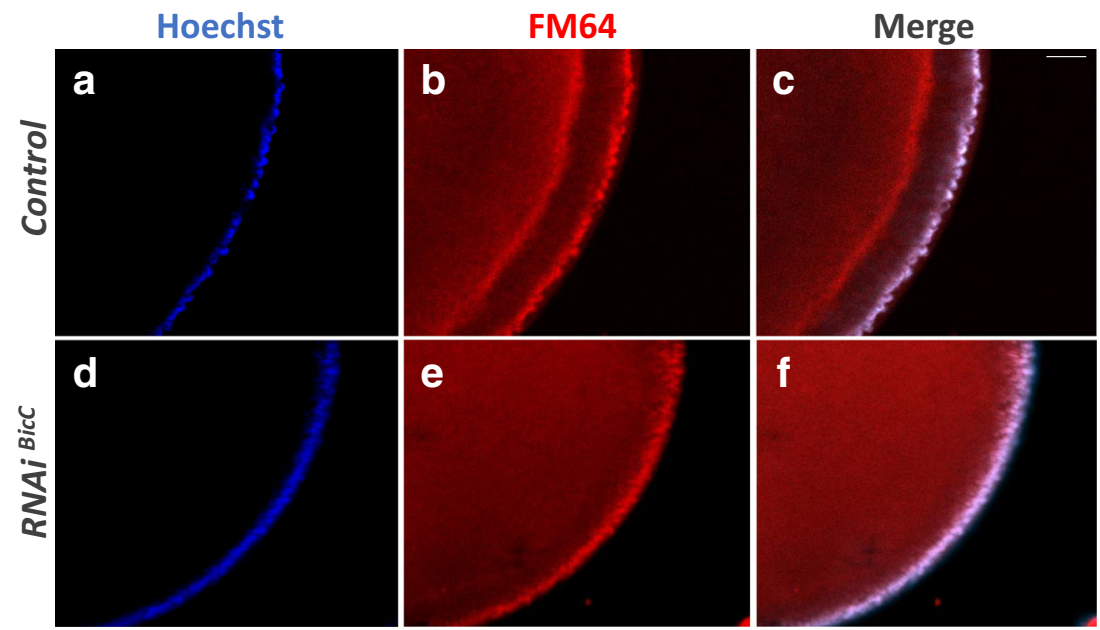

(Mahone et al. 1995). We observed that the primary effect of silencing $\mathrm{Rp}-\mathrm{BicC}$ is a disorganized pattern of the follicular epithelium from the early previtellogenic stages until the end of vitellogenesis. The cells look loose and lacking the association among each other. At a first glance, the phenotype might be related to atresia, characterized by a degenerative process of the follicular epithelium, in which chorion deposition does not occur yielding non-viable oocytes (Huebner 1981b; Medeiros et al. 2011b). However, in the silenced $R p$-BicC ovaries the follicular cells are able to synthesize the chorion.

Our results agrees with the $\mathrm{BicC}$ phenotype described for the hemipteran Nilaparvata lugens, which seems to affect yolk loading in the egg (Zhang et al. 2015), but we provide a plausible hypothesis to explain the mechanism that causes the phenotype. $R p-B i c C$ is required for epithelial integrity and cell polarity as evidenced by the changes of distribution of endocytic pathway markers (Gaffield et al. 2009), suggesting that the apical-basal polarity of the follicular cells is a crucial requirement for vitellogenesis. We propose that transcytosis plays a role in the uptake of yolk precursors into the oocyte. This has been suggested for insects of different orders, such as Carausius morosus (Phamatodea), Podisus nigrispinus (Hemiptera), and Apis mellifera, Melipona quadrifasciata, Mischocyttarus cassununga, and Pachycondyla curvinodis (Hymenoptera) (Assis et al. 2019; Dohanik et al. 2018; Fausto et al. 2005; Giorgi et al. 1998; Ronnau et al. 2016). Up to now, vitellogenin uptake by the oocyte had exclusively been attributed to the phenomenon of patency (Davey 1981; Huebner and Anderson 1972b; Huebner and Injeyan 1980). Our results provide evidence of a transcellular route for vitellogenin transport through the follicular epithelium during oogenesis in $R$. prolixus.

It has been recently demonstrated that $R p-A T G 6$ and $R p$ $A T G 8$, part of PI3P-kinase complex that regulates the endocytic and autophagy machinery are essential for yolk accumulation (Pereira et al. 2020; Vieira et al. 2018). The phenotype of silenced $R p$-ATG6 females shares similarities with the one of $R p-B i c C$ - unviable, small and white eggs that accumulate a minor fraction of yolk. $R p-A T G 8$ is required for the maternal biogenesis of autophagosomes and has a role, although not exclusive, in follicular atresia. This indicates that $R p$-ATG6 seems to only affect the oocyte uptake of yolk rather than the integrity of the follicular epithelium and the patterning of the chorion. This led us to propose that autophagy is involved in a process that requires cell polarity and that $R p$ $B i c C$ might be an upstream gene that contributes to polarization.

The sequencing of many insect genomes poses a challenge ahead for comparative and evolutive studies of the cellular and molecular mechanisms of development, in particular in hemimetabolous insects. Studies on the classical model $R$. prolixus, as the one presented here, will open new and exciting paths to understand the genetic interactions that regulate the formation of the egg and its subsequent developmental processes.

Supplementary Information The online version contains supplementary material available at https://doi.org/10.1007/s00427-021-00673-0.

Acknowledgements The authors thank all members of Rivera-Pomar and Andrés Lavore labs for fruitful discussions, L. Canavoso (CIBICI - CCT CONICET, Córdoba, Argentina) for kindly sharing the anti-vitellin antibody, A. Nazar for her contribution to develop the in situ protocol for $R$. prolixus, and Reprosemyx S.A. for kindly allowing the use of their confocal facility. R.R.-P is investigator and A.P postdoctoral fellow of CONICET.

Funding This work was funded by ANPCyT and UNNOBA.

\section{References}

Aguirre SA, Frede S, Rubiolo ER, Canavoso LE (2008) Vitellogenesis in the hematophagous Dipetalogaster maxima (Hemiptera: Reduviidae), a vector of Chagas' disease. J Insect Physiol 54:393402

Altschul SF, Gish W, Miller W, Myers EW, Lipman DJ (1990) Basic local alignment search tool. J Mol Biol 215:403-410 
Assis MQ, Dohanik VT, Oliveira LL, Zanuncio JC, Serrao JE (2019) Evidence for a transcellular route for vitellogenin transport in the telotrophic ovary of Podisus nigrispinus (Hemiptera: Pentatomidae). Sci Rep 9:16441

Atella GC, Gondim KC, Machado EA, Medeiros MN, Silva-Neto MA, Masuda H (2005) Oogenesis and egg development in triatomines: a biochemical approach. An Acad Bras Cienc 77:405-430

Aviv T, Lin Z, Ben-Ari G, Smibert CA, Sicheri F (2006) Sequencespecific recognition of RNA hairpins by the SAM domain of Vts1p. Nat Struct Mol Biol 13:168-176

Beament JW (1946) The formation and structure of the chorion of the egg in an hemipteran, Rhodnius prolixus. Q J Microsc Sci 87:393-439

Berni M, Fontenele MR, Tobias-Santos V, Caceres-Rodrigues A, Mury FB, Vionette-do-Amaral R, Masuda H, Sorgine M, da Fonseca RN, Araujo H (2014) Toll signals regulate dorsal-ventral patterning and anterior-posterior placement of the embryo in the hemipteran Rhodnius prolixus. Evodevo 5:38

Blariza MJ, Leyria J, Canavoso LE, Soria NW, Garcia BA (2016) Dynamics of expression of two vitellogenin genes in the Chagas disease vector Triatoma infestans: Analysis throughout previtellogenesis and vitellogenesis. Acta Trop 156:100-107

Bonhag PF (1958) Ovarian structure and vitellogenesis in insects. Annu Rev Entomol 3:137-160

Bouts DM, Melo AC, Andrade AL, Silva-Neto MA, Paiva-Silva Gde O, Sorgine MH, da Cunha Gomes LS, Coelho HS, Furtado AP, Aguiar EC, de Medeiros LN, Kurtenbach E, Rozental S, Cunha ESNL, de Souza W, Masuda H (2007) Biochemical properties of the major proteins from Rhodnius prolixus eggshell. Insect Biochem Mol Biol 37:1207-1221

Braz GR, Abreu L, Masuda H, Oliveira PL (2001) Heme biosynthesis and oogenesis in the blood-sucking bug, Rhodnius prolixus. Insect Biochem Mol Biol 31:359-364

Brito T, Julio A, Berni M, de Castro Poncio L, Bernardes ES, Araujo H, Sammeth M, Pane A (2018) Transcriptomic and functional analyses of the piRNA pathway in the Chagas disease vector Rhodnius prolixus. PLoS Negl Trop Dis 12:e0006760

Büning JR (1994) The insect ovary: ultrastructure, previtellogenic growth, and evolution, 1st edn. Chapman \& Hall, London ; New York

Buxton PA (1930) The Biology of A Blood-Sucking Bug, Rhodnius Prolixus. Trans Royal Entomol Soc London 78:227-256

Coelho HS, Atella GC, Moreira MF, Gondim KC, Masuda H (1997) Lipophorin density variation during oogenesis on Rhodnius prolixus. Arch Insect Biochem Physiol 35:301-313

Costa-Filho A, Werneck CC, Nasciutti LE, Masuda H, Atella GC, Silva LF (2001) Sulfated glycosaminoglycans from ovary of Rhodnius prolixus. Insect Biochem Mol Biol 31:31-40

Coura JR, Borges-Pereira J (2012) Chagas disease. What is known and what should be improved: a systemic review. Rev Soc Bras Med Trop 45:286-296

Chagas CRJ (1909) Nova tripanosomíase humana. Estudos sobre a morphologia e o ciclo evolutivo do Schizotrypanum cruzi n. gen. n. esp., agente da nova entidade mórbida do homem. Mem Inst Oswaldo Cruz 1:159-218

Chicoine J, Benoit P, Gamberi C, Paliouras M, Simonelig M, Lasko P (2007) Bicaudal-C recruits CCR4-NOT deadenylase to target mRNAs and regulates oogenesis, cytoskeletal organization, and its own expression. Dev Cell 13:691-704

Chmiel NH, Rio DC, Doudna JA (2006) Distinct contributions of KH domains to substrate binding affinity of Drosophila P-element somatic inhibitor protein. RNA 12:283-291

Davey KG (1965) Reproduction in the insects. W.H. Freeman, San Francisco

Davey KG (1981) Hormonal control of vitellogenin uptake in Rhodnius prolixus Stal. Am Zool 21:701-705

de Cuevas M (2005) Drosophila Oogenesis. eLS:1-7
Dohanik VT, Goncalves WG, Oliveira LL, Zanuncio JC, Serrao JE (2018) Vitellogenin transcytosis in follicular cells of the honeybee Apis mellifera and the wasp Polistes simillimus. Protoplasma 255: 1703-1712

Driever W, Nusslein-Volhard C (1988a) The bicoid protein determines position in the Drosophila embryo in a concentration-dependent manner. Cell 54:95-104

Driever W, Nusslein-Volhard C (1988b) A gradient of bicoid protein in Drosophila embryos. Cell 54:83-93

Drummond AJ, Rambaut A (2007) BEAST: Bayesian evolutionary analysis by sampling trees. BMC Evol Biol 7:214

Fausto AM, Gambellini G, Mazzini M, Cecchettini A, Giorgi F (2005) Yolk uptake through the follicle epithelium in the ovary of the stick insect Carausius morosus. Arthropod Struct Develop 34:89-95

Fortes P, Salvador G, Consoli FL (2011) Ovary development and maturation in Nezara viridula (L.) (Hemiptera: Pentatomidae). Neotrop Entomol 40:89-96

Gaffield MA, Tabares L, Betz WJ (2009) Preferred sites of exocytosis and endocytosis colocalize during high- but not lower-frequency stimulation in mouse motor nerve terminals. J Neurosci 29:1530815316. https://doi.org/10.1523/JNEUROSCI.4646-09.2009

Gamberi C, Hipfner DR, Trudel M, Lubell WD (2017) Bicaudal C mutation causes myc and TOR pathway up-regulation and polycystic kidney disease-like phenotypes in Drosophila. PLoS Genet 13: e1006694

Ginzburg N, Cohen M, Chipman AD (2017) Factors involved in early polarization of the anterior-posterior axis in the milkweed bug Oncopeltus fasciatus. Genesis:55

Giorgi F, Falleni A, Cecchettini A, Gremigni V (1998) A fat body derived protein is selectively sulfated in the stick insect ovary by transcytosis through the follicular epithelium. Biol Cell 90:183-197

Gondim KC, de Oliveira PL, Masuda H (1987) The roles of haemolymphatic lipoproteins in the oogenesis of Rhodnius prolixus. Mem Inst Oswaldo Cruz 82(Suppl 3):89-92

Harrison RE, Huebner E (1997) Unipolar microtubule array is directly involved in nurse cell-oocyte transport. Cell Motil Cytoskeleton 36: 355-362

Huebner E (1981a) Nurse cell-oocyte interaction in the telotrophic ovarioles of an insect, Rhodnius prolixus. Tissue Cell 13:105-125

Huebner E (1981b) Oocyte-follicle cell interaction during normal oogenesis and atresia in an insect. J Ultrastruct Res 74:95-104

Huebner E, Anderson E (1970) The effects of vinblastine sulfate on the microtubular organization of the ovary of Rhodnius prolixus. J Cell Biol 46:191-198

Huebner E, Anderson E (1972a) A cytological study of the ovary of Rhodnius prolixus. Cytoarchitecture and development of the trophic chamber. J Morphol 138:1-40

Huebner E, Anderson E (1972b) A cytological study of the ovary of Rhodnius prolixus. I. The ontogeny of the follicular epithelium. J Morphol 136:459-493

Huebner E, Anderson E (1972c) A cytological study of the ovary of Rhodnius prolixusII. Oocyte differentiation. J Morphol 137:385415

Huebner E, Injeyan H (1980) Patency of the follicular epithelium in Rhodnius prolixus: A re-examination of the hormone response and technique refinement. Can J Zool 58:1617-1625

Huebner E, Injeyan H (1981) Follicular modulation during oocyte development in an insect: formation and modification of septate and gap junctions. Dev Biol 83:101-113

Johnson PE, Donaldson LW (2006) RNA recognition by the Vts1p SAM domain. Nat Struct Mol Biol 13:177-178

Larkin MA, Blackshields G, Brown NP, Chenna R, McGettigan PA, McWilliam H, Valentin F, Wallace IM, Wilm A, Lopez R, Thompson JD, Gibson TJ, Higgins DG (2007) Clustal W and Clustal X version 2.0. Bioinformatics 23:2947-2948 
Lavore A, Esponda-Behrens N, Pagola L, Rivera-Pomar R (2014) The gap gene Kruppel of Rhodnius prolixus is required for segmentation and for repression of the homeotic gene sex comb-reduced. Dev Biol 387:121-129

Lavore A, Pagola L, Esponda-Behrens N, Rivera-Pomar R (2012) The gap gene giant of Rhodnius prolixus is maternally expressed and required for proper head and abdomen formation. Dev Biol 361: $147-155$

Lavore A, Pascual A, Salinas FM, Esponda-Behrens N, MartinezBarnetche J, Rodriguez M, Rivera-Pomar R (2015) Comparative analysis of zygotic developmental genes in Rhodnius prolixus genome shows conserved features on the tracheal developmental pathway. Insect Biochem Mol Biol 64:32-43

Letunic I, Bork P (2016) Interactive tree of life (iTOL) v3: an online tool for the display and annotation of phylogenetic and other trees. Nucleic Acids Res 44:W242-W245

Leyria J, Orchard I, Lange AB (2020) Transcriptomic analysis of regulatory pathways involved in female reproductive physiology of Rhodnius prolixus under different nutritional states. Sci Rep 10: 11431

Lutz DA, Huebner E (1980) Development and cellular differentiation of an insect telotrophic ovary (Rhodnius prolixus). Tissue Cell 12:773794

Lutz DA, Huebner E (1981) Development of nurse cell-oocyte interactions in the insect telotrophic ovary (Rhodnius prolixus). Tissue Cell 13:321-335

Lynch JA, Roth S (2011) The evolution of dorsal-ventral patterning mechanisms in insects. Genes Dev 25:107-118

Machado EA, Atella GC, Gondim KC, de Souza W, Masuda H (1996) Characterization and immunocytochemical localization of lipophorin binding sites in the oocytes of Rhodnius prolixus. Arch Insect Biochem Physiol 31:185-196

Machado EA, Oliveira PL, Moreira MF, de Souza W, Masuda H (1998) Uptake of Rhodnius heme-binding protein (RHBP) by the ovary of Rhodnius prolixus. Arch Insect Biochem Physiol 39:133-143

Mahone M, Saffman EE, Lasko PF (1995) Localized Bicaudal-C RNA encodes a protein containing a KH domain, the RNA binding motif of FMR1. EMBO J 14:2043-2055

Medeiros MN, Logullo R, Ramos IB, Sorgine MH, Paiva-Silva GO, Mesquita RD, Machado EA, Coutinho MA, Masuda H, Capurro ML, Ribeiro JM, Cardoso Braz GR, Oliveira PL (2011a) Transcriptome and gene expression profile of ovarian follicle tissue of the triatomine bug Rhodnius prolixus. Insect Biochem Mol Biol 41:823-831

Medeiros MN, Ramos IB, Oliveira DM, da Silva RC, Gomes FM, Medeiros LN, Kurtenbach E, Chiarini LB, Masuda H, de Souza W, Machado EA (2011b) Microscopic and molecular characterization of ovarian follicle atresia in Rhodnius prolixus Stahl under immune challenge. J Insect Physiol 57:945-953

Melo AC, Valle D, Machado EA, Salerno AP, Paiva-Silva GO, Cunha ESNL, de Souza W, Masuda H (2000) Synthesis of vitellogenin by the follicle cells of Rhodnius prolixus. Insect Biochem Mol Biol 30: 549-557

Mesquita RD, Vionette-Amaral RJ, Lowenberger C, Rivera-Pomar R, Monteiro FA, Minx P, Spieth J, Carvalho AB, Panzera F, Lawson D, Torres AQ, Ribeiro JM, Sorgine MH, Waterhouse RM, Montague MJ, Abad-Franch F, Alves-Bezerra M, Amaral LR, Araujo HM, Araujo RN, Aravind L, Atella GC, Azambuja P, Berni M, Bittencourt-Cunha PR, Braz GR, Calderon-Fernandez G, Carareto CM, Christensen MB, Costa IR, Costa SG, Dansa M, Daumas-Filho CR, De-Paula IF, Dias FA, Dimopoulos G, Emrich SJ, Esponda-Behrens N, Fampa P, Fernandez-Medina RD, da Fonseca RN, Fontenele M, Fronick C, Fulton LA, Gandara AC, Garcia ES, Genta FA, Giraldo-Calderon GI, Gomes B, Gondim KC, Granzotto A, Guarneri AA, Guigo R, Harry M, Hughes DS, Jablonka W, Jacquin-Joly E, Juarez MP, Koerich LB, Lange AB,
Latorre-Estivalis JM, Lavore A, Lawrence GG, Lazoski C, Lazzari CR, Lopes RR, Lorenzo MG, Lugon MD, Majerowicz D, Marcet PL, Mariotti M, Masuda H, Megy K, Melo AC, Missirlis F, Mota T, Noriega FG, Nouzova M, Nunes RD, Oliveira RL, Oliveira-Silveira G, Ons S, Orchard I, Pagola L, Paiva-Silva GO, Pascual A, Pavan MG et al (2015) Genome of Rhodnius prolixus, an insect vector of Chagas disease, reveals unique adaptations to hematophagy and parasite infection. Proc Natl Acad Sci U S A 112:14936-14941

Miller MA, Pfeiffer W, Schwartz T (2010) Creating the CIPRES Science Gateway for inference of large phylogenetic trees. Gateway Comput Environ Workshop (GCE): $1-8$

Mohler J, Wieschaus EF (1986) Dominant maternal-effect mutations of Drosophila melanogaster causing the production of doubleabdomen embryos. Genetics 112:803-822

Nusslein-Volhard C (1977) Genetic analysis of pattern-formation in the embryo ofDrosophila melanogaster : Characterization of the maternal-effect mutantBicaudal. Wilehm Roux Arch Dev Biol 183:249-268

Nusslein-Volhard C, Roth S (1989) Axis determination in insect embryos. CIBA Found Symp 144:37-55 discussion 55-64, 92-38

Oliveira PL, Gondim KC, Guedes DM, Masuda H (1986) Uptake of yolk proteins in Rhodnius prolixus. J Insect Physiol 32:859-866

Park S, Blaser S, Marchal MA, Houston DW, Sheets MD (2016) A gradient of maternal Bicaudal-C controls vertebrate embryogenesis via translational repression of mRNAs encoding cell fate regulators. Development 143:864-871

Pascual, A. (2019). Genómica del desarrollo embrionario de Rhodnius prolixus. Facultad de Ciencias Exactas, Área Ciencias Biológicas UNLP, 180

Pereira J, Diogo C, Fonseca A, Bomfim L, Cardoso P, Santos A, Dittz U, Miranda K, de Souza W, Gioda A, Calderon ERD, Araripe L, Bruno R, Ramos I (2020) Silencing of RpATG8 impairs the biogenesis of maternal autophagosomes in vitellogenic oocytes, but does not interrupt follicular atresia in the insect vector Rhodnius prolixus. PLoS Negl Trop Dis 14:e0008012

Raikhel AS (2005) Vitellogenesis of disease vectors, from physiology to genes. In: Marquardt W (ed) Biology of Disease Vectors. Elsevier Academic Press, London

Raikhel AS, Dhadialla TS (1992) Accumulation of yolk proteins in insect oocytes. Annu Rev Entomol 37:217-251

Reynolds ES (1963) The use of lead citrate at high $\mathrm{pH}$ as an electronopaque stain in electron microscopy. J Cell Biol 17:208-212

Ribeiro JM, Genta FA, Sorgine MH, Logullo R, Mesquita RD, PaivaSilva GO, Majerowicz D, Medeiros M, Koerich L, Terra WR, Ferreira C, Pimentel AC, Bisch PM, Leite DC, Diniz MM, da, S.G.V.J.J.L., Da Silva ML, Araujo RN, Gandara AC, Brosson S, Salmon D, Bousbata S, Gonzalez-Caballero N, Silber AM, AlvesBezerra M, Gondim KC, Silva-Neto MA, Atella GC, Araujo H, Dias FA, Polycarpo C, Vionette-Amaral RJ, Fampa P, Melo AC, Tanaka AS, Balczun C, Oliveira JH, Goncalves RL, Lazoski C, RiveraPomar R, Diambra L, Schaub GA, Garcia ES, Azambuja P, Braz GR, Oliveira PL (2014) An insight into the transcriptome of the digestive tract of the bloodsucking bug, Rhodnius prolixus. PLoS Negl Trop Dis 8:e2594

Ronnau M, Azevedo DO, Fialho M, Gonclaves WG, Zanuncio JC, Serrao JE (2016) Changes in follicular cells architecture during vitellogenin transport in the ovary of social Hymenoptera. Protoplasma 253:815820

Roth S, Schupbach T (1994) The relationship between ovarian and embryonic dorsoventral patterning in Drosophila. Development 120: 2245-2257

Rozen S, Skaletsky H (2000) Primer3 on the WWW for general users and for biologist programmers. Methods Mol Biol 132:365-386

Schupbach T, Roth S (1994) Dorsoventral patterning in Drosophila oogenesis. Curr Opin Genet Dev 4:502-507 
Schupbach T, Wieschaus E (1986) Maternal-effect mutations altering the anterior-posterior pattern of the Drosophila embryo. Roux Arch Dev Biol 195:302-317

Schupbach T, Wieschaus E (1991) Female sterile mutations on the second chromosome of Drosophila melanogaster. II. Mutations blocking oogenesis or altering egg morphology. Genetics 129: 1119-1136

Smith CB, Betz WJ (1996) Simultaneous independent measurement of endocytosis and exocytosis. Nature 380:531-534

Snodgrass RE (1935) Principles of insect morphology, 1st edn. McGrawHill Book Company, inc., New York, London

Sorrivas de Lozano, V., Morales, A., Yañez, M.J. (2014). Principios y práctica de la Microscopía Electrónica. in: UAT, E. (Ed.), CONICET Bahía Blanca.

Stothard P (2000) The sequence manipulation suite: JavaScript programs for analyzing and formatting protein and DNA sequences. BioTechniques 28(1102):1104

Urbani E (1970) A survey on some aspects of oogenesis in Dytiscus, Cybister and Hygrobia (Coleoptera). Acta Embryol Exp (Palermo) 3:281-297

Valdimarsson G, Huebner E (1989) The development of microtubular arrays in the germ tissue of an insect telotrophic ovary. Tissue Cell $21: 123-138$
Vieira PH, Bomfim L, Atella GC, Masuda H, Ramos I (2018) Silencing of RpATG6 impaired the yolk accumulation and the biogenesis of the yolk organelles in the insect vector R. prolixus. PLoS Negl Trop Dis 12: 00006507

Wanderley-Teixeira V, Teixeira AA, Cunha FM, Costa MK, Veiga AF, Oliveira JV (2006) Histological description of the midgut and the pyloric valve of Tropidacris collaris (Stoll, 1813) (Orthopetera: Romaleidae). Braz J Biol 66:1045-1049

Wigglesworth VB (1934) The physiology of ecdysis in Rhodnius prolixus (Hemiptera). II. Factors controlling moulting and metamorphosis. Q J Microscopy Sci 77:191-222

Wigglesworth VB (1939) The Principles of Insect Physiology. Methuen, London

Wigglesworth VB (1953) The origin of sensory neurons in an insect. Q J Microscopy Sci 93:93-112

Wigglesworth VB (1964) The hormonal regularion of growth and reproduction in insects. Adv Insect Physiol 2

Zhang BX, Huang HJ, Yu B, Lou YH, Fan HW, Zhang CX (2015) Bicaudal-C plays a vital role in oogenesis in Nilaparvata lugens (Hemiptera: Delphacidae). J Insect Physiol 79:19-26

Publisher's note Springer Nature remains neutral with regard to jurisdictional claims in published maps and institutional affiliations. 